\title{
"FOREBYGGING AV KRIMINALITET" ALTFOR BREDT OG ALTFOR SMALT
}

\author{
Av Hedda Giertsen
}

"Forebygging av kriminalitet" gjør et godt førsteinntrykk. Rett og riktig og viktig, pent og ordentlig, akseptert i de fleste miljøer. Svigermors drøm. Uangripelig.

Det kan man forstå ved å se på noen trekk ved dette begrepet:

A) "Forebygging av kriminalitet" er et vidt og omfattende begrep som rommer alle slags tiltak:

- tiltak mot alle

- tiltak mot dem som står på grensen til å begå lovbrudd

- straff og tiltak mot dem som allerede har begått lovbrudd

Disse tiltakene er gitt egne navn: primær-, sekundær- og tertiær-forebyggende tiltak.

- forebygging av lovbrudd

- forebygging av skader på grunn av lovbrudd ${ }^{1}$

- tiltak mot enkeltpersoner

- tiltak for å endre strukturer, muligheter for å begå lovbrudd

Tiltakene blir vurdert utfra

- kortsiktige

- langsiktige virkninger

og er rettet mot alle slags former for lovbrudd

- økonomiske lovbrudd

- veitrafikklovbrudd

- sedelighetslovbrudd

- vinningslovbrudd

- voldslovbrudd

- osv, osv.

B) Enda viktigere er det at "forebygging av kriminalitet" er et positivt ladet begrep som alle er enige om. Hvem kan gå mot? Iallefall ikke regjering og Storting som for 1992 har pekt ut forebyggende virksomhet som ett av sine særlige satsingsområder i følge St.prp. nr. 1 (1991-2). Å gå mot forebygging av kriminalitet er som å gå mot Det Gode og støtte elendigheten.

"Forebygging av kriminalitet" er et vidt og vagt begrep som enhver kan legge sine utvalgte oppfatninger inn i. Nettopp fordi det er upresist, snakker i generelle vendinger og er lite brukbart empirisk sett, er det velegnet og nyttig for so- 
siale formål. Det er som politiske avtaler: Alle kan være enige om en litt uklar tekst, fordi alle kan legge sine intensjoner inn i den. Det er ikke noe ukjent fenomen at begreper får en slik sosial funksjon, "narkotika" (Bruun \& Christie 1968) er ett eksempel, "mangelfullt utviklede og/eller varig svekkede sjelsevner" fra rettspsykiatrien er et annet. Og akkurat nå lever "forebygging av kriminalitet" et populært og aktivt liv i politikken.

Forebygging av kriminalitet er blitt et magisk begrep, som samler nasjonen og åpner pengesekker.

Men selvom "forebygging av kriminalitet" fremstår som en enkel og ukontroversiell sak, bare et spørsmål om administrasjon av de gode hensikter, viser nærmere kjennskap til begrepet at heller ikke "forebygging av kriminalitet" er fullstendig glatt, uten særtrekk og spesielle egenskaper. "Forebygging av kriminalitet" kan ses som et lite blaff av Herbert Tingstens tanke om at ideologiene er døde. Men spørsmålet er ikke om de lever eller ikke, men om vi ser dem eller $i k k e^{2}$.

Jeg vil derfor innlede til utveksling av synspunkter om hvilke forståelser, oppfatninger, verdier og ideologier som ligger til grunn for idéen om at kriminalitet kan forebygges generelt, og for enkelte tiltak spesielt. Og hva som ligger i forlengelse $a v$ forebygging av kriminalitet, hvilke følger det får for den som tiltakene rettes mot og for vår forståelse av lovbrudd og reaksjoner på lovbrudd.

\section{EN MEDISINSK TANKE}

Idéen om forebygging av kriminalitet er knyttet til den moderne tenkemåde og kommer fra opplysningstiden med sin optimistiske tro på at det fins en Utvikling med retning Fremover og at det går an å forbedre samfunnet. Tanken om forebygging har sitt utspring i naturvitenskapen, i medisinen, med sine erfaringer om at det går an å finne årsaken til sykdommer og dermed helbrede og til og med forebygge dem. Denne erfaringen hentet fra kropp og helse, ble brukt som analogi og overført på samfunnet, ikke bare som et tankebilde, men som et alvorlig uttrykk for hvordan samfunnet fungerte. Man tenkte seg en rekke uønskete fenomener som fattigdom, latskap og lediggang, alkoholbruk og kriminalitet som samfunnets sykdommer. Og den som bare fant årsaken, kunne helbrede dem - eller enda bedre, forebygge dem.

Denne behandlingstanken fra medisin og legevitenskap har som sitt grunnleggende utgangspunkt at det er enighet mellom alle parter om behandlingen, at det er fellesskap i interesser. Det er til hver enkelts og fellesskapets beste at det blir satt i verk tiltak for å bøte på sykdom. Behandler og behandlet har det samme målet: klienten skal bli frisk. Derfor er den medisinske profesjonen bygget opp som en rekke spesialiseringer som utfyller hverandres kunnskaper. Antagelsen om felles interesser mellom behandler og behandlet kan sees som et 
typisk trekk ved behandlingsapparatet. I motsetning til det som gjelder i kontrollapparatet. Her har man som utgangspunkt at det er motsetning i interesser mellom den som blir siktet, tiltalt eller fengslet og myndighetene. Derfor er det bygget inn rettssikkerhetsgarantier som skal sikre at myndighetene ikke begår overgrep (Aubert 1958).

Når man tar i bruk et slikt behandlingsperspektiv løfter man samtidig tanken om lovbrudd over i naturvitenskapelige tankebaner og tanken om felles interesser til beste for hver enkelt, fellesskapet og samfunnets fremadgående utvikling, får forrang. Uenighet og motsetninger i verdier og fortolkninger, interesser og oppfatninger kommer lett i bakgrunnen. Sosialteknologien får gode muligheter.

Men det finns andre sammenhenger å se lovbrudd i, enn en naturvitenskapelig/medisinsk, andre tanker om lovbrudd enn at det skal forebygges.

\section{HARMONI ELLER KONFLIKT - \\ OG HVOR SKAL KONFLIKTEN PLASSERES}

Når man bruker en medisinsk modell, fremstår forebygging som harmoniske tiltak og noe alle er enige om. Og alle kan nok være enige på det generelle planet om at lovbrudd bør forebygges. Men like etter at en slik enighet er etablert, opstår det uenigheter og motsetninger av flere slag. Forebygging av kriminalitet er ikke uten konflikter. Spørsmålet er hvor de plasseres.

Antall butikktyveri har økt. Det har mengden av varer i butikken også. Butikkinredningene er forandret, fra disker med varer og kjøpmann på den ene siden og kunden på den andre, er det blitt reol på reol med varer man bare kan plukke med seg, helst i butikkens trillevogn. Reklamen har endret seg, fra fornuftige fristelser rettet mot husmorambisjoner om hvitt tøy, til livsstilsreklamer for cola, olabukser og fritidsliv rettet mot barn og unge. Både oppmerksomheten om tingenes betydningsfullhet og mulighetene for å skaffe sig dem ulovlig, er styrket, både de materielle og ideologiske omgivelsene er endret. Og resultatet ble at butikktyveriene $ø \mathrm{kte}^{3}$. Vi kjenner sammenhengen, men vi skrur ikke butikkinnredningene og reklamen tilbake til 1950-årene. Handelsstanden lager plakater om hvor flaut der er å bli tatt, som kunde.

Et eksempel fra et annet område, er "Barnas trafikklubb" som skulle få barn til å ta ansvar for seg selv i trafikken, slik at muligheten for å bruke bil ikke skulle innskrenkes. Berit Ås gikk i sin tid ut mot "Barnas trafikklubb" og pekte på at man la anavaret på barna, innskrenket deres lekemuligheter, og samtidig fratok trafikkmyndigheter og den enkelte bilist ansvar. Trafikkulykker hvor barn blir skadet eller drept er ikke et spørsmål om opplæring av barn, men om å skille bilene ut fra områder for gående og lekende. Nå er denne tanken etterhvert godtatt. Bilens selvfølgelige rett er ikke lenger like selvfølgelig overalt ${ }^{4}$. 
Et mer aktuelt eksempel på samme tenkemåte er det kriminalitetsforebyggende tiltaket "Fra bagatell til helvete" som blant annet består av en brosjyre som viser hvordan det går med deg fra du står igjen utenfor skoleporten når det ringer inn, til du tar en pakke røyk i en butikk, som igjen utvikler seg til at du stjeler en kasse øl, til hjemme-alene-fest, til å stjele en bil, slå ned en dame, for så å dø på en do av overdose ${ }^{5}$.

Det er ungdommen som skal ta ansvaret for ikke å gå i grøfta. Selvfølgelig må den det. Ta sin del. Men de er ikke alene om ansvaret. Det ser ut til at noen forebyggende tiltak har et trekk felles med tradisjonelle strafferettslige tiltak: De rettes inn mot dem det går an å ta, som har få muligheter til å protestere og bli hørt.

Man kunne tenke seg en "Fra bagatell til helvete" for andre også, for eksempel Tezschners byråd i Oslo: "Fra bagatell . . ." når de med et pennestrøk sløyfet bevilgninger til Ungbo, fritidsklubber og storbyavdelingen ". . . til helvete" når unge ikke hadde noe sted å være og møysommelig oppbyggete miljøer og kompetanse mistet samlingssted. Man kunne tenke seg en "Fra bagatell til helvete" for voksne i forskjellige situasjoner.

Det er så vidt begynt, ser det ut til. Noen steder har man fått opp interessekonflikten mellom foreldre med sitt alkoholbruk på den ene siden og hensynet til ungdommens drikking på den andre. På et seminar i 1992 fortalte førstekonsulent Anne Høgetveit i Sosialdepartementet om prøveprosjekt for organisering av tiltak overfor unge rusmiddelbrukere i 5 kommuner. En av kommunene var Harstad. Der hadde man blant annet prøvd å gjøre foreldre oppmerksomme på eget rusmiddelbruk:

"Arbeidet har så langt blitt vurdert som vellykket og prosjektet har skapt relativt stor debatt, noe som var så og si fraværende før" (Høgetveit 1992 s. 30).

Og i Bærum, hvor prosjektleder Tove Nakken (1993) tok opp foreldres alkoholvaner. Et uvant tema på foreldremøter.

Men det er en relativt uorganisert og maktsvak gruppe man pirker borti, når foreldre utfordres.

Eksemplene er ment som grunnlag for å ta opp noen viktige trekk ved én type forebyggende tiltak: Holdningskampanjer rettet mot personer og grupper. Et slående trekk ved denne typen tiltak som tar sikte på å endre atferd gjennom å endre holdninger, er at konflikter og interessemotsetninger tilsløres. Det giøres ved at konflikten flyttes fra person/omgivelser inn i personen. Det er inne i våre personer at stengslene mot lovbrudd skal bygges opp, slik at andres interesser for eksempel handelsstandens kjøpepress ikke ska hemmes ${ }^{6}$. Når konflikter mellom interesser er dysset ned, kan man individualisere årsaken til lovbrudd ${ }^{7}$.

Samtidig er det slik at bak tiltak rettet mot holdninger og atferd ligger det en oppfatning om at det er den enkelte som i vesentlig grad er årsak til lovbrudd. 
Og tiltakene befester og styrker i sin tur denne oppfatningen. Tiltak har derfor ikke bare en praktisk betydning, men også en ideologisk. De bidrar til å bekrefte den oppfatningen som lå til grunn for tiltaket.

Man kan analysere tiltak mot andre typer lovbrudd på samme måte: utfra hvilke forståelser av lovbruddet som er i bruk, hvilke oppfatninger som blir bekreftet - og hvilke forståelser som kunne vært brukt. Her er et eksempel:

\section{Illegale kjemiske rusmidler}

Tiltak mot narkotika retter seg i hovedsak mot stoffet, det er stoffet som er problemet (i motsetning til tiltak rettet mot alkohol, som har som utgangspunkt at det er enkelte personer som ikke klarer å styre sitt forbruk). Alle fire ledd: produksjon, omsetning, besittelse og bruk av narkotika er kriminalisert i ulik grad. Og man tar i bruk kontroll og tekniske virkemidler for å hindre tilgangen på stoff: kontroll på grensene, spaning, tipstelefon, politi, telefonavlytting, narkotikahunder, undersøkelse av kroppens hulrom, domstoler og fengselsstraff.

Det er mulig å kriminalisere alle fire ledd, fordi det ikke er noen sterke etablerte økonomiske interesser som står bak.

Men vi ser ikke bruken av narkotika bare som kontrollproblem, men også som helse- og sosialproblem. Så det er opprettet behandlingstilbud på sykehus, i kollektiv osv. Bak disse tiltakene ligger en oppfatning om at rusmiddelbrukere trenger hjelp av terapeutisk art, trening $\mathrm{i}$ annen livsstil ol. for å slutte å bruke kjemiske rusmidler. Men det er tiltak grunnet i kontrollperspektivet som trekker til seg flest ressurser.

Det finns også et annet perspektiv på bruken av kjemiske rusmidler som ikke spør etter problemer, men tar utgangspunkt $\mathrm{i}$ brukernes erfaringer og opplevelse av stoffbruk - hvilken mening den har for dem, og så prøve å forstå bruken. En slik antropologisk tilnærming har Hans Christian Sørhaug (1988) brukt i en studie av stoffbrukere i Oslo: Stoffet og den kjemiske rusen er noe å fylle seg med.

Kanskje kan man se paralleller til stoffbruk i den voldsomme og høye musikken unge hyller seg inn i og går opp i? I tilstrømningen til New Age? I spiseforstyrrelser som bulemi og anoreksia. I den økte bruken av beroligende legemidler. Noen personer er bærere av grunnleggende forstyrrelser i samfunnet: Hva skal vi fylle oss med?

Fra dette kan vi linjen trekkes over til sider ved vårt moderne samfunn som skaper tomhet. En slik analyse er brukt i "Den gode fiende" (Christie \& Bruun 1985) som peker på trekk som høy grad av aldersegregring, en langstrakt ungdomstid preget av enveiskommunikasjon fra lærere og fjernsyn som tilsammen er det mange unge bruker største delen av sin tid på8. Men aller viktigst er det at vi har et samfunn som er materielt rikt, men fattigere på samlende sosiale opp- 
levelser sammenliknet med tidligere samfunn, blant annet fordi vi bygger ned både samfunnsmessige og mer private feiringer og sosiale høydepunkter ${ }^{9}$.

Disse ulike synene på hva som er problemet når det gjelder bruk av noen typer rusmidler og andre typer lovbrudd, gjenspeiler to grunnleggende forskjellige perspektiver:

- Man kan se uønskete handlinger som Noe Annet, ikke bare i moralsk forstand, men også når man skal prøve å forstå dem. Man ser dem som noe svært forskjellig og fremmed, noe helt annerledes og utenfor vårt vanlige liv.

- Eller lovbrudd sees som noe som er nøye integrert $i$ andre sider ved samfunnet, hektet fast med utallige hemper, baksiden av en forside som noen lever høyt på. Men denne måten å se lovbrudd på, er vanskelig å bruke for den som skal forebygge dem. Britta Kyvsgaard (1990b) siterer Leitenberg som sier (i dansk oversettelse):

"Når årsagsforholdene er komplekse og viklet ind i vort politiske og økonomiske system, er de vanskelige at forandre. Det betyder, at man - uden at overdrive for meget - kan karakterisere meget af det kriminalpræventive arbejde, vi laver, som at sætte plastre, beregnet for bumser, på store, åbne sår. Det burde ikke forbavse, at det sjældent hjælper og ofte skader" (s. 191).

På samme måte kan man diskutere hva som er årsak til ulike typer voldslovbrudd og hva som er passende tiltak. Det får bli en annen gang.

Det fins så mange måter å tolke lovbrudd på, så mange perspektiver å sikte seg inn langs. Valg av fortolkning og vår måte å forstå lovbrudd på, er avgiørende for hva vi siden giør. I forlengelsen av våre oppfatninger, ligger et tiltak og venter. Er det den enkelte som bærer årsaken med seg, eventuelt hvordan, i kraft av biologiske kjennetegn, oppvekstmiljø eller moralsk ansvar? Er det situasjoner og muligheter som skaper lovbrudd?

Som et illustrerende eksempel kan nevnes en liten notis fra Frankfurter Rundschau 27.4.1993. Ifølge "Präsident des Regierungsbezirks Lüneburg" ble fire av ti dødsulykker i løpet av de tre siste årene, plassert på kontoen gatetrær.

Hva bestemmer hvilke årsaker vi velger å bruke?

\section{HVORDAN MÅLE FOREBYGGING}

Nytter det? Hjelper det? Slike spørsmål er det tanken om forebygging fanger oss inn i. Og svaret er at det må måles. Flere artikler og arbeider ${ }^{10} \operatorname{tar}$ opp vanskeligheten med å vite om forebyggende tiltak hjelper. Ett problem er at man ikke făr isolert de enkelte faktorene, det er så mye som blander seg inn, som Ekblom (1992) påpeker". . . the weather even"'l.

Når det ikke går særlig bra å måle det enkelte forebyggende tiltakets betyd- 
ning - hva giør man da? Fortsetter standhaftig i samme retning, tenker at man må da kunne finne ut hvordan faktorenes betydning kan isoleres og måles. Men det er ikke måleinstrumentene det er noe galt med. Det er tanken bak som teller.

i) Hvorfor skal man isolere enkelte momenter? De opptrer aldri isolert. Ønsket om å isolere dem, kan man tenke seg er knyttet til et ønske om å kunne dirigere og kontrollere det man ser som kriminalitetsfremmende faktorer. Men den enkelte faktor har ingen konstant betydning, faktorenes betydning er avhengig av hvilke andre faktorer de virker sammen med. (For eksempel kunne man ønske seg å vite noe om medias betydning for angst for kriminalitet. Men medias betydning er ikke konstant, den varierer med situasjonen leser-lytter-seer står i: Om det er en eldre person som sjelden går ut og ikke har egen erfaring med det som skjer, eller om det er en ung person som føler han kan ordne opp i situasjoner og selv ser hva som foregå $\mathrm{r}^{12}$ ).

Det er den ene innvendingen mot ønsket om å måle.

ii) Dessuten virker ikke faktorer automatisk på folk. Noen forebyggende tiltak har et slags mekanistisk syn på mennesker.

Albert \& Reiss (1992) viser til kritikk av "rational choice"-teorier hvor personer fremstår som nøkterne veiere av fordeler og ulemper. Reiss viser til kritikk fra dem som mener at man også må ta i betraktning hvordan en lovovertreder opplever risikoen for å bli tatt. Men også dette er et begrenset syn.

Kyvsgaard (1990a) retter en mer grunnleggende kritikk mot enkle modeller i forebygging og kritiserer menneskesynet som er i bruk i "Scared Straight", en film som viser unge i møte med fanger som skal avskrekke de unge fra lovbrudd: "Endelig kan der også rettes kritik mod den forsimplede psykologiske tankegang, sådanne afskrækkelsesforsøg er baseret på" - nemlig forsøk med rotter. Kyvsgaard gjør leseren oppmerksom på at mennesker som kjent er litt mer komplisert og lever $\mathrm{i}$ en verden som gir flere og undertiden motstridende impulser, enn tilfellet er for en rotte i et laboratorieforsøk (s. 124).

Man kan ikke bygge på en enkel stimulus-respons modell. For mellom mulighet og handling ligger valget. Og valget er blant annet bestemt av vilken oppfatning og forståelse folk har av sin situasjon og sine handlinger. De kan være rare og uvanlige og fremmede for andre, men de har betydning.

Det viser Malin Åkerstrøms bok "Crooks and Squares" (1985) som beskriver oppfatninger og forståelser hos personer som satt i fengsel, dømt for tradisjonelt tyveri, moderne vinningslovbrudd og bruk av kjemiske rusmidler ${ }^{13}$. Hvilken betydning vil forebyggende tiltak ha på dem?

Hvis vi ser på et tertiærforebyggende tiltak som fengsel, viser det seg at lovbryter og myndigheter ofte er uenige. Men i utgangspunktet kan de enes om at straffen er et onde: 
- De er delvis enige om at den virker avskrekkende: myndighetene ser det som et onde som avholder en person fra å begå handlinger som kan føre til straff, lovovertrederen ser det som et onde som gjør at han bør sørge for ikke å bli tatt.

- De er uenige om at straffen bidrar til å endre holdningen til lovbrudd: myndighetene mener at straffen er uttrykk for misbilligelse overfor lovovertrederen. Som på sin side nok vil være enig $\mathrm{i}$ at trekk ved straffen kan være ydmykende, men det kommer an på hvordan man tar det. Det som gjør at du mister status i ditt eget miljø er at du ikke tar fengselsstraffen som en mann. Så paradoksalt nok kan straffen som var ment å stigmatisere en lovovertreder, bli en mulighet til å vise at han er en virkelig mann, som tåler en støyt og holder ut. I sitt miljø.

Dette var også en virkning av "Scared Straight". Fremfor å avskrekke, kan filmen oppfattes som en utfordring til å vise styrke og uvirkelighet: "Det, behandlere og andre antager virker frastødende, kan indeholde elementer, der virker tiltrækkende på personer i en anden livssituation" (Kyvsgaard 1990a, s. 121).

- Eller lovovertrederne ser straffen som en omkostning, noe man må regne med, en utgift til inntekts erhvervelse. Åkerstrøm refererer en samtale mellom en lovbryter og en såkalt "do-gooder" fra en bok av Parker \& Allerton (1962):

"Now do you really think, honestly, that this keeping on going back to prison all the time is worth it? ... But you don't want to spend all your life in prison, do you?"

"No."

"Well then ..."

"I'm not going to spend all my life in prison. I have only spent a third of it there, up to now. You said all."

"All right, then, a third - do you think that's worth it?"

"Yes" (s. 90).

Det er uenigheter mellom intervjupersonen og myndigheter om hvordan straffen skal forstås. Og ikke bare uenighet. Man kunne også kalle det konflikt, ettersom myndighetene har makt til å handle ut fra sin forståelse ${ }^{14}$.

Vi ser den samme uenigheten når det gjelder oppfatningen av behandlingstilbud mellom den som blir behandlet og behandler. Åkerstrøm viser trekk ved behandlingen, som gjør den lite egnet som utgangspunkt for mellomnenneskelig samhandling:

- Behandling tar for gitt at det er noe galt med din mentale tilstand

- og din bakgrunn. $\AA$ degradere bakgrunn og familien, som ofte er de eneste personer en fange har, er i bunn og grunn det samme som å degradere deg

- terapi kan brukes som en form for verdi-imperialisme - ved å definere personens verdier som riktige eller gale, og ikke bare handlingen utfra lovverket. 
Fangen opplever mangel på respekt for andre verdier. Noen ganger kommer denne uenigheten om definisjonen av handling og person og kampen om hvilken forståelse som skal gjelde, opp til overflaten:

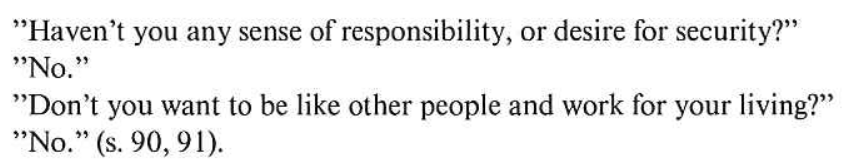

Den som har makten vinner - på ett plan. Men det er ved hjelp av makt og ikke utfra enighet eller overbevisende argumentasjon.

Jeg kan høre innvendingene blomstre opp: Dette gjelder jo bare et lite utvalg fanger! Man kan ikke slutte fra disse til alle andre. Akkurat dette peker på en viktig egenskap ved begrepet "forebygging av kriminalitet" som skal tas opp, men ikke ennå.

Likevel vil jeg si at $\AA$ kerstrøms data og diskusjoner gjelder utover den spesielle situasjonen for fanger. $\AA$ bli plukket ut og få tiltak rettet mot seg kan oppleves som degraderende og stigmatiserende, uansett hvor god meningen måtte være.

iii) Det tredje momentet jeg vil ta opp når det gjelder spørsmålet om å måle virkningen av forebygging, knytter seg til bruken av kunnskapene. En ting er å samle inn informasjoner om personer, sette det opp i tabeller, gi forslag til sammenheng og forståelse, kanskje bringe opp ulike fortolkninger. Noe annet er å gå den motsatte veien: $\AA$ bruke aggregerte data til å peile ut enkeltpersoner eller grupper for så å sette inn tiltak mot dem. For eksempel vet vi at av alle 14-17 åringer som tas for tyveri i 1988 var det $50 \%$ som ble registrert for nye lovbrudd $\mathrm{i}$ en 3-års periode ${ }^{15}$. Men denne kunnskapen gjør oss ikke istand til å si hvem av 14-17 åringene som vil falle tilbake.

Det kan føre til fatale feilslutninger, om man ikke tar hensyn til, at det er forskjell på det å tolke et materiale som allerede er innsamlet og det å forutsi ${ }^{16}$. Vi kjenner det fra diskusjonen om sikring, Vergerådsloven av 1896 og dagens diskusjon om inkapasitering. Behandlingssiden ligger ikke langt etter. Kristin Skjørten (1993) viser at kunnskapen om at personer som begår sedelighetslovbrudd ofte selv har vært ofre for slike lovbrudd, kan snus rundt.

Her tror jeg vi er ved foten av en uvilje jeg føler overfor forebygging av lovbrudd, og som jeg har vanskelig for å forstå fordi jeg også mener at det er ålreit å være mot lovbrudd. To trekk ved forebyggingen dukker opp gjennom punktene ii) og iii):

- den virker manipulativ

- og preget av mangel på likeverdighet og vanlig menneskelighet og anstendighet.

Ekblom (1992) skriver om et forebyggingstiltak i England. På midten av 
80-tallet samlet det seg store mengder ungdom i en by i øst-England hver fredag kveld og skapte bråk. Home Office vill gjøre noe med dette og satte igang undersøkelser. Det viste seg at problemet ikke så mye var mengden bråk som konsentrasjonen. H. O. laget "multiple" tiltak: sørget for at puber og kaféer stengte på forskjellige tider, laget kurs i vennlige utkastelser og "urban planning approaches". Det er vel og bra for alle parter og samtidig er det noe i dette jeg reagerer mot.

Myndigheter skaffer seg kunskap med ett eneste formål: $\AA$ forebygge lovbrudd ved å forandre betingelser og atferd hos en gruppe som kanskje ikke visste at dette var grunnen til intervjuerens vennlige tilnærming og interesse for akkurat hans syn. Om han făr vite om formålet, kan han ikke alltid overskue virkningen av det han sier. Det er mangel på likeverd i relasjonen. Og denne mangelen knytter seg blant annet til at målet er å påvirke atferden, altså et manipulativt mål. Nå er jeg ikke uenig i at man skal prøve å påvirke folk til å la være å gjøre noe man syns er galt. Men det bør gjøres med åpne kort, selvom dette heller ikke innebærer noen garanti mot overgrep.

Man kan reise to spørsmål om disse sidene ved forebygging:

i) Er tiltakene effektive og

ii) er de innenfor rammen av det anstendige overfor den enkelte.

Til det første: Eksempler som er nevnt ovenfor, viser at man ikke kan gå utfra at folk lar seg forutsi, og at noen gjør motstand mot at bli betraktet og behandlet slik. Det er svært usikkert om det nytter.

I en annen sammenheng har Einar Økland (1986) tatt opp at vi har ulike syn på verden, at det er mange om røyndomsbeinet og at noen gjerne vil tre sin bestemmelse ned over andre. Men utfra de kretser han har erfaring fra, er det ikke så lett å få til. Denne erfaringen er selvsagt ikke noe bevis, men utsagnet er intressant som eksempel på mot-tro til troen på forebygging:

"Så mange har prøvd - med alle tilgjengelege middel, pedagogiske, forkynnande, regulerande - å forme kvar og ein av oss i sit bilde, i sitt syn, etter sitt uttrykk. Ingen har til denne tid klart det. Dei hadde klart det i fall det ikkje fants mottrykk. Folk skaper heile tida si eiga motrøynd ved hjelp av sine uttrykk. Spør ikkje meg kvar dei får uttrykksevna frå. Mi tru er at mennesket er ekspressivt, eg trur vi må ta for gitt at det produserer medvit og uttrykk" (s. 20).

Til det andre punktet: Det er grunnleggende fremmed og umenneskelig når noen setter seg fore å skulle forutsi og forebygge andre folks handlinger. En fange som ikke passer inn i programmet vil derfor paradoksalt nok nettopp opprettholde sin egen respekt og menneskelighet ${ }^{17}$.

Tiltak mot personer og grupper som tar sikte på å endre atferd og livsstil reiser vanskelige spørsmål om hvem som kan definere andre som risiko-person og dermed stå i fare for å påføre andre en identitet de ikke har bedt om og stempel 
som en eller annen form for avviker. Og det reiser spørsmål om hvem som forvalter Det Gode Liv. Med hvilken rett går man løs på å forandre andre folk? Som er noe annet enn å reagere på handlinger, eventuelt lovbrudd som allerede er giort.

Er nå kriminologisk forskningen i sin alminnelighet så mye bedre på disse punktene, vil kanskje noen spørre. Eksemplet som Ekblom refererte, kan brukes til å diskutere spørsmålet, for hendelsen er ikke ny. En gang på sluten av 60-tallet strømmet ungdom til badebyene på Englands sørkyst og inntok overklassens steder og sloss mot hverandre. Stanley Cohen (1972) skrev om hendelsen i boka "Folk devils and moral panics: the creation of mods and rockers". Målet hans var ikke å forebygge. Boka ga en beskrivelse ikke bare av ungdommenes situasjon og syn på det som hadde hendt, men også av det voksne samfunnets reaksjoner ("the creation of mods and rockers"), samtidig som begge deler ble brukt til å si noe om det samfunnet som skaper slike situasjoner og fortolkninger. Boka ga økt innsikt i en hendelse og betingelsene for denne hendelsen. Den handlet ikke bare om "De Andre", men også om "oss".

\section{UANGRIPELIG}

Et kjennetegn ved "forebygging av kriminalitet" (som jeg var inne på og lovte å komme tilbake til) er at man ikke får tak på det. Det fremstår som uangripelig fordi det er vidt og omfattende. For hver konkrete innvending som reises, vil forebyggingens talspersoner kunne si: Men det er vi klar over, det der er et unntak. Ikke noe tiltak gjelder alle. I andre tilfeller nytter det å forebygge.

Men forebyggende tiltak rettet mot enkeltpersoner og grupper vil lett komme ut for slike vanskeligheter som $\AA$ kerstrøms undersøkelse gir innblikk i.

Det er også et annet særtrekk ved Åkerstrøms bok, som er interessant i denne sammenhengen. Hun har et helt annet utgangspunkt enn svært mange forebyggingstiltak. Hun gikk til de innsatte og spurte om deres oppfatning av situasjonen og bragte frem viktige opplysninger om variasjoner i fangers oppfatninger. Og hun gik inn i en likeverdig relasjon med intervjupersonen.

Mens tanken om tertiærforebygging av kriminalitet giennom fengsel, er basert på annen type informasjon og tilnærmingsmåte, nemlig hva som er samfunnets oppfatning av hva som trengs og aksepteres. Se for eksempel begrunnelser for resosialiserende og rehabiliterende tiltak. Et viktig argument for undervisning $i$ NOU 1992:19 er at fanger trenger opplæring i livskompetanse og livsmestring. Men er det noe §kerstrøms undersøkelse viser, er det at disse fangene ikke har noen opplevelse av å mangle evne til å mestre sine liv, innen den livsstilen de har valgt. Kanskje det ligger noe her - at tanken at lovovertredere er velgende og handlende personer, er uvant og fremmed og har små sjanser mot den tanken at de er marionetter som dingler hjelpeløst i skjebnens elendighetstråder. 
Livsmestring og livskompetanse - på hvilke premisser? Det sies ikke. Fordi det er opplagt. For oss. At noen ikke vil innordne seg middelklassens regler, er både uforståelig og uhellsvangert.

Forebygging nytter. Må nytte. Overfor de fleste er det mulig å forebygge lovbrudd. Jeg făr en følelse av å ha hørt dette før. Det har jeg også. Men det dreide seg ikke om forebygging. $\AA$ diskutere "forebygging av kriminalitet" er som å diskutere straffens almenpreventive virkning. Her er noen tydelige likheter ${ }^{18}$ :

- Både forebygging og almenprevensjon er vide og vage begreper.

- De virker intuitivt riktige: Det hjelper at en politimann plasseres på gaten. Han forebygger at folk begår lovbrudd. Det høres rimelig at folk lar være med å begå lovbrudd når de ser de strenge følgene av det. Det finns eksempler på begge deler. Men til syvende og sist blir det et spørsmål om tro:

Johs. Andenæs (1977) sier: "Det sterkeste grunnlag for troen på almenprevensjonen er fremdeles den vel kjente erfaring at frykten for ubehagelige konsekvenser er en sterkt motiverende faktor i de fleste av livets forhold ...." (s. 220).

Britta Kyvsgaard (1990b) sier: "Det er muligt at forebygge kriminalitet. Men ..." (s. 190). Det høres som besvergelser. Problemet i begge tilfeller er at man generaliserer utfra sin egen sunne fornuft og dagliglivets erfaringer som foregår i relasjoner preget av uformell kontroll - og over til virkninger av formell kontroll rettet personer med tilknytning til mange forskjellige slags miljøer.

Om vi skal komme videre i diskusjonen om forebygging, er det viktig å gjøre som Johs. Andenæs når det gjaldt almenprevensjonen: å nyansere og konkretisere diskusjonen. Og da er vi tilbake til en situasjon vi kjenner: Til hele spektret av kriminologisk forskning.

Det er som om noen har prøvd å ta en snarvei da de lanserte idéen om "forebygging av kriminalitet", forbi all møysommelig innsamlet kunnskap og diskusjoner om fortolkninger, menneskesyn og forståelsesmåter. "Forebygging av kriminalitet" er svaret på dagens krav om en kjapp løsning på samfunnssykdommer. Enda en grunn til min uvilje mot forebygging, er at denne tanken frister til å forenkle spørsmålene om hva ligger bak lovbrudd og tro at det finns noen forte og generelle løsninger.

Diskusjonen hittil har vært rettet mot tiltak overfor personer og grupper. Men forebygging omfatter også andre tiltak:

- Tekniske hindringer som hindrer først og fremst vinningslovbrudd som innbrud og tyveri. De betyr sjelden forebygging av kriminalitet, men oftest flytting av kriminalitet fra dem som har råd til å installere hindringer, til dem som ikke har råd til det. Også ofrene for lovbrudd samles blant dem som i utgangspunktet har en vanskelig livssituasjon (Kyvsgaard 1990b). 
- En annen type er tiltak rettet mot alle, for eksempel tiltak rettet mot bomiljøer. De innebærer ikke slike risikoer som er nevnt ovenfor. Det ser også ut til at det er gode erfaringer fra flere av dem. Men bedring av bomiljø blir ikke bare begrunnet med forebygging av lovbrudd, men også som et mål i seg selv. Det er viktig, også for å unngå uheldige virkninger. Om målet er at det skal bli mindre lovbrudd, at folk skal føle seg tryggere, hender det at virkningen blir den motsatte. All opmerksomhet rettet mot mulighetene for lovbrudd og spørsmål om øking og minsking har ført til at folk er blitt mer bekymret (Kyvsgaard referer Rosenbaum (1988), s. 174). Det er noe merkelig i å skulle trenge en slik begrunnelse for å gjøre bomiljøene bedre når det kan være tilstrekkelig som et mål i seg selv. Og hvis det skulle vise seg utfra en eller annen måling at det "ikke hjelper" - skal vi da la være å gjøre bomiljø bedre?

Det er et kriminalitetsfiksert samfunn som trenger slike begrunnelser for å øke trivsel.

Det er også andre typer tiltak som retter seg mot store grupper: fritidsklubber, ungdomskonserter, aktivitetshus, kaféer med spesielt tilbud til unge. Og det fins tilbud rettet inn mot spesielle grupper, som seilturer, overlevelsesturer. Kanskje disse tiltakene forebygger lovbrudd. Det mest iøynefallende med dem er at de lager rammer for at folk kan møtes og innen disse rammene foreta seg noe, snakke sammen, oppleve noe. Det er tilbud som trengs fordi det er færre naturlige møtesteder for folk med mye tid og lite arbeid. Må vi begrunne slike tiltak i forebygging av lovbrudd eller går det an å bruke andre begrunnelser? Av hensyn til hvem velger vi "forebygging av kriminalitet" - og hvilket bilde av barn og unge er det som stiger opp av de stadig gjentatte begrunnelser om "forebygging av kriminalitet", som vi voksne gladelig gir i bytte for en slump penger til det gode formål?

\section{SOM HÅND I HANSKE MED ADMINISTRATIV TENKEMÅTE}

C) Et tredje kjennetegn ved "forebygging av kriminalitet" er at det passer som hånd $\mathrm{i}$ hanske med administrativ tenkemåte. Tanken om forebygging av kriminalitet inviterer til å sette opp mål og måle resultatet: her trengs et budsjett over ressurser: penger, tid, folk - og et forventet resultat. Og så kommer regnskapets time hvor det som faktisk har skjedd skal måles mot det man håpet.

Men straks man gjør det, forvandles "Forebygging av kriminalitet". Det som før var dagliglivets erfaringer (det nytter å si fra at noe er galt og gi ros osv.) får nå en annen karakter. Ikke fordi erfaringene ikke gjelder lenger, men fordi de er plantet inn i en annen sammenheng. Det du kan si og mene og handle ut fra til daglig som en midlertidig antakelse, binder deg opp og får en langt større tyngde når det brukes av et administrativt apparat med makt til rådighet. Det som kan fungere i en sammenheng hvor personer står i et nokså gjensidig avhengighets- 
forhold til hverandre, får en annen betydning når den ene parten gjør det $\mathrm{i}$ kraft av en jobb eller profesjon og har makt.

Denne forvandlingen kan også leses ut fra forskjeller i språk. Dagliglivets beskrivelser er ikke lenger fine nok. At politifolk skal patruljere til fots, kan ikke sies slik. Det heter primærforebyggende tiltak. Noen grupper med unge gutter i Oslo har begått alvorlige voldshan.'linger, og politi og andre har satt i verk tiltak, blant annet "klarte man å isolere enkelte". Ordene letter fra bakken og blir nesten-empiriske beskrivelser. Språket blir fint og fjernt. Den som ikke kjenner virksomheten fra før, vet ikke hva som har hendt. Språket lukker for innsyn.

Samtidig som det å kalle tiltaket forebygging binder opp og forplikter: Vi må si hvor mye det virker! Det er ikke nok bare å ha politi-fotpatruljer, virkningene må også måles. Disse endringene i språk og måling skjer ikke på tiltakenes premisser, men på administrasjonens og politikkens. Keiseren skal ha sitt og han tar snart alt sammen.

Er tanker, idéer og tiltak først kommet in i administrasjonen, forvandles de, og lever sitt eget liv her inne. I foredrag om forebygging er det alltid et innslag om den administrative oppbyggingen og sammenhengen. Det kan man forstå når det er relevant for å forstå tiltakene. Om det hadde blitt med det! Men det blir ofte også snakk om stillingsplasseringer, lønnsplassering osv., slikt som det har en symbolsk betydning innenfor administrasjonen hvor det er et uttrykk for grad av aksept.

Det formålsrasjonelle er en tenkemåte vi forstår. Myndighetene krever at investeringer skal kaste noe av seg, og beskrives i et språk slik at administrasjonen kan måle. Den skal ordne opp. Men det er vel med dette målet, som med lykken - i følge Dag Solstad som sier: "Lykken er et altfor lite mål for menneskene".

Nå kan man ikke klandre en administrasjon for at den setter seg praktiske, formålsrasjonelle "nå-lykken-mål". Det er enhver administrasjons plikt og oppgave. Men det fins andre oppgaver som også må ivaratas.

Dag Østerberg (1991) har inndelt samfunnets institusjoner i kategorier alt etter virksomhet og rasjonalitet eller tenkemåte.

i) En kategori omfatter institusjoner som produserer varer og tjenester. Hit hører industri, servicebedrifter, offentlig administrasjon osv. Den dominerende tenkemåten kan karakteriseres som formålsrasjonell.

ii) En annen kategori tar seg av reproduksjon av folk og arbeidskraft, men også reproduksjon som et mål i seg selv, slik det kommer til uttrykk i familieliv og søndagstur. Og tenkemåten er preget av omsorgsrasjonalitet.

iii) En tredje kategori omfatter institusjoner som samordner ulike interesser og mål, tar opp spørsmål det er uenighet om, tar avgjørelser og setter dem ut i 
livet. Dette er politikkens institusjoner. Tenkemåten er preget av sunn fornuft og maktens logikk.

iv) En fjerde kategori omfatter også institusjoner som samordner, men denne gangen prinsipper, verdier og tenkemåter. Hit hører kunst og vitenskap som holder levende og fornyer kulturmønstre og forståelsesmåter og diskusjoner om hvordan omgivelsene kan forstås, forholdet mellom natur og mennesker og mennesker og samfunn. Her er tenkemåten preget av refleksjon og innsikt.

Noen ganger kan man få inntrykk av at den formålsrasjonelle tankegangen får et mer og mer bredt gyldighetsområde - at administrasjonenes økende makt (gjennom nye administrative virkemidler som for eksempel virksomhetsplanlegging) gjør at personer i andre typer institusjoner bøyer sine tanker slik at de blir tilpasset administrasjonen - i innhold og språk. At det som holder på å skje er at administrasjonen koloniserer vår tenkemåte ${ }^{19}$. Det er en fare for at samfunnsvitenskapen i sin iver etter midler til prosjekter og aksept og anseelse kan komme til å bruke administrasjonens mål på sin egen virksomhet. Diskusjonen om "Forebygging av kriminalitet" gir eksempler på det. Et av dem bidrar Albert J. Reiss, jr. (1992) med. I artikkelen "Crime prevention in urban communities: a western perspective" drøfter han ulike typer forebyggingstiltak: straff og inkapasitering, medikament-terapi og psykoterapi og strukturelle endringer. Men alle disse tiltakene blir diskutert ut fra ett eneste kriterium: effektivitet. Han drøfter inkapasitering og medikament-terapi uten å bringe inn spørsmålet om anstendighet og menneskelige hensyn overfor dem tiltakene skal rettes mot. Verken Reiss eller foredraget er uten posisjon. Reiss er mangeårig president $\mathrm{i}$ The International Society for Criminology og foredraget ble holdt på det 47. internasjonale kurs "Crime Prevention in Urban Community". Kyvsgaard (1990b) tar derimot opp etiske problemer ved inkapatisering og ved kriminalpreventive målinger (s. 186, 184). Men Kyvsgaard gir også størst oppmerksomhet til spørsmålet om virkning og effektivitet.

Så en fare er at vi glemmer andre hensyn enn de effektive. Fordi lovovertredere, lovbrudd og situasjoner knyttet til lovbrudd er så sammensatte og mangfoldige, fordi det er vanskelig å vite virkningene av tiltak og aller mest fordi mange tiltak griper inn i folks private liv, er det viktig å balansere ønsket om effektivitet og forbedringer med hensynet til vanlig menneskelig anstendighet og tradisjonell rettssikkerhet.

En annen fare er at vi i tråd med administrasjonens ønsker bare regner de momentene som relevante som vi tror vi kan gjøre noe med. For det vil prege vår forståelse av hva lovbrudd er og innsnevre vårt perspektiv.

Østerbergs inndelinger finner vi igjen i de gruppene som har med forebygging å gjøre:

- personer som står for tiltakene: praktikere og politikere 
- administrasjonen som ordner opp med stillingshjemler, lønn, plassering i strukturer, og legger til rette for vurdering av tiltakene - preget av formålsrasjonell tenkemåte.

- Og forskere som prøver å se forebygging i en videre sammenheng, som har sin forankring i fjerde kategori.

Med ulike forankringer, diskuteres forebygging utfra ulike utgangspunkt. Min uro over forebyggingen er at det administrativet skal regnes som det eneste gyldige.

For forskning har flere oppgaver enn å minske lovbrudd, selvom den kanskje kan bidra til det inni mellom. Den bør bringe frem ulike tilnærmings- og forståelsesmåter, ha som sitt fremste mål å øke innsikt og erkjennelse, også de ubehagelige, og fortsatt rette oppmerksomheten mot tankemodeller som er i bruk, analysere dem og finne ut hvilke verdier, menneskesyn og forestillinger som ligger til grunn for dem. Og på denne måten bryte hegemonier til bestemte tenkemodeller. Forskningen har også som mål å være seg bevisst sine fortolkningsmodeller: Hva sier det om vårt samfunn at vi er så opptatt av "Forebygging av kriminalitet'?

"Forebygging av kriminalitet" gaper altfor høyt og vil omfatte alle slags tiltak mot alle slags lovbrudd. Det er et ord som kan brukes i politikken, men det blir for stort og uklart og uhåndterlig i vitenskapen. Her kan det opptre ikke som redskap, men som en gjenstand for nysgjerrighet og analyse.

Samtidig er begrepet altfor smalt. I iveren etter å se resultater og at noe blir gjort, er det lett å klippe bort perspektiver som bringer inn hensyn til enkeltpersoner, og forståelsesmåter som ikke gjør det så lett å hindre uønskete handlinger.

\section{Litteratur}

Andenæs, Johs.: Nyere forskning om almenprevensjonen - status og kommentar. Trykt i Nordisk Tidsskrift for Kriminalvidenskab 1977, s. 61 flg. Sitatet er hentet fra antologien Fra spredte felter. Tanum Norli 1982.

Aubert, Vilhelm: Legal justice and mental health. Psychiatry 1958.

Balvig, Flemming: Reaktioner på kriminalitet i samfundets centrum og periferi. I Nordisk samarbeidsråd for kriminologi. Rapport fra kontaktseminaret. Sundvollen 1979.

Bruun, Kettil og Nils Christie: Alcohol Problems. The conceptual Framework. Proceedings of the 28th Congress on Alcohol and Alcoholism. Vol 2. Sept. 15-20. Hillhouse Press, 1968.

Christie, Nils og Kettil Bruun: Den gode fiende. Oslo 1985.

Cohen, Stanley: Folk devils and moral panics: the creation of mods and rockers. Basil Blackwell. Oxford 1972.

Ekblom, P.: Urban crime prevention: development of policy and practice in England. I International annals of criminology. International Society of Criminology. Vol. 30 - nr. 1 \& 2. 1992. 
Ericsson, Kjersti \& Monika Rudberg: Bråk i klassen. Oslo 1981.

Furre, Berge: Draumen om femtiåra. Syn og Segn nr. 2/1993.

Hellesnes, Jon: Systemet, livsverda og mediavaset. Referat av Jon Hellesnes sitt innlegg ved Dag og Tid sitt jubileums seminar 12.3.1992. Dag og Tid. 8.10.1992.

Hernes, Gudmund: Reproduksjon av ulikhet. Hvilken rolle spiller skolen? Christian Ejler. 1975.

Høgetveit, Anne: Ungdom og rus. Sosialdepartementets prøveprosjekt for organisering av tiltak overfor unge rusmisbrukere i 5 kommuner. I Samordning av lokale kriminalitetsforebyggende tiltak (SLT). Kriminalitets forebygging, Ungdomskriminalitet, Barnevern. Rapport fra SLT-seminar 1992. Det kriminalitetsforebyggende råd 1992.

Justisminister Grete Faremo: Regjeringens prioriterte satsingsområder mot barne- og ungdomskriminalitet fram mot år 2000. I Samordning av lokale kriminalitetsforebyggende tiltak (SLT). Kriminalitetsforebygging, Ungdomskriminalitet, Barnevern. Rapport fra SLT-seminar 1992. Det kriminalitetsforebyggende råd 1992.

Kriminalstatistikker for 1975 (forbrytelser), 1985, 1989, 1991. Statistisk sentralbyrå.

Kyvsgaard, Britta: Skræmt til lovlydighed? Dansk forsøg med aversionsterapi. I Forebyggelsens veje og vildveje. Kriminalistisk Institut. Københavns Universitet 1990a.

Kyvsgaard, Britta: . . . Men der er da noget, der virker. Resultater fra forsøg med kriminalpræventive tiltag. I Forebyggelsens veje og vildveje. Kriminalistisk Institut. Københavns Universitet 1990b.

Nakken, Tove: Kriminalitetsforebyggende atbeid blant ungdom med utgangspunkt i erfaringer fra Bærum kommune. Seminar Institutt for kriminologi 3.2.1993.

NOU 1991:10. Flere gode levekår for alle. Forebyggelsesstrategier.

NOU 1992:19. Opplæring i norske fengsler. Kompetanse og livsmestring.

Reiss jr., Albert J.: Crime prevention in urban communities: a western perspective. I International annals of criminology. International Society of Criminology. Vol. 30 nr. 1 \& 2. 1992.

Skjørten, Kristin: Vold i hverdagen. Oslo 1994.

St. prp. nr. I (1991-92). Justisdepartementet.

Sørhaug, Hans Kristian: Identitet: Grenser, autonomi og avhengighet. Alkoholpolitik. Vol. 5, 1988:1.

Økland, Einar: Kan virkeligheten beskrives? I Kan virkeligheten beskrives. Oslo 1986.

Østerberg, Dag: Universitet og vitenskap i dagens samfunn. Samtiden nr. 1/1991.

Åkerstrøm, Malin: Crooks and Squares. Lifestyles of thieves and addicts in comparison to conventional people. Transaction books. 1985.

Adresse: Hedda Giertsen

Institutt for kriminologi

Universitetet i Oslo

St. Olavs Plass 5

N-0130 Oslo 


\section{Noter}

1) Se f.eks. Albert J. Reiss jr. 1992, s. 23, 24

2) "Femtiåra var ei tid med ein verdifellesskap som gjekk så vidt at folk ikkje trudde dei hadde verdiar. Idear som likeverd, sosial rettferd, utjamning vart sett på som "fornuftige", ikkje ideologiske. For Herbert Tingsten hadde forkynt "ideologiane var døde", og drapsmammen var den sosiale og politiske fornuft, slik han kom til uttrykk i det industrielle verferdsamfunns reformspiral" (Berge Furre 1993).

3) Antall butikktyverier/naskerier er tidoblet fra 1959/60 til 1985/86, fra omtrent 600 til 6.000. (Beregnet utfra Kriminalstatistikker fra 1975, 1985, 1989). For 1991 viser tallene en nedgang til ca. 4.500 .

4) Albert J. Reiss jr. (1992) beskriber hvordan tiltak for å bedre trafikksikkerheten i USA endret seg fra opplæring av bilkjørere, dvs tiltak rettet mot personer, til endringer av veibanen, og tiltak som minsker skaden når ulykken har hendt (bilbelter, luftputer). Det er tiltak som endrer situasjon og mulighet og er uavhengig av personvalg, som gir resultater. Men i motsetning til Berit Ås, er Reiss ikke opptatt av hvilke oppfatninger og fordeling av ansvar og skyld som ligger bak de ulike typene tiltak.

5) Flere andre spørsmål som kan rettes mot dette tiltaket, gjelder avskrekkingstiltak generelt. Som et eksempel kan nevnes Kyvsgaards (1990a) beskrivelse av ulike syn på filmen "Scared Straight" som viser ungdommer konfrontert med fanger dømt for alvorlige lovbrudd. Resultatet av filmen var langt fra entydig positivt. Det ser ut til at filmen avskrekket dem som ikke har begått lovbrudd tidligere, men har en "boomerang"-effekt og øker lovbrudd blant andre ungdommer.

6) Se f.eks. Ekblom (1992) som tar opp denne interessekonflikten.

7) Dette gjelder ikke bare når det gjelder å forebygge lovbrudd, men også andre samfunnsproblemer:

- Når barn ikke lykkes i skolen, kommer det til syne i karakterene, et uttrykk for elevenes arbeidsinnsats og evner. Slik blir inntrykket. Men det er fortsatt slik at skolen er laget av og for middelklassen og skolesystemet fungerer ikke bare som et sted for formidling av kunnskaper og holdninger, men også som en sorteringsmaskin til spredning av personer ut $\mathrm{i}$ forskellige posisjoner med ulik grad av belønninger (Hernes (1975), Ericsson og Rudberg (1981)).

- Arbeidsløshet tas ofte som et uttrykk for den enkeltes vellykkethet, til tross for at strukturelle forhold gjør at stadig mindre del av den voksne arbeidsføre befolkningen får adgang til lønnet arbeid. Når folk holdes utenfor lønnet arbeid, oppstår blant annet spørsmålet om økonomisk livsgrunnlag. Det løses først og fremst gjennom trygd, men den gis bare i bytte mot en grunn. Av ca. 37.000 personer som er uføretrygdet med nevrose, rusproblem eller andre psykiske problemer som årsak, er ca. 3.000 under 35 år (årstall er ikke angitt i teksten, men det er antagelig rundt 1987/88. hg). Fra 1987 til 1988 økte i antall personer under 35 som ble uføretrygdet på grunnlag av psykiatrisk diagnose (psykisk utviklingshemning ikke medregnet) med $26 \%$ for kvinner og $20 \%$ for men (NOU 1991:10). En slik øking sier mer om samfunnsmessige muligheter enn om folks egnethet, men årsaken fremstår som individuell.

8) Dette punktet kan kanskje diskuteres. Hvor mye hører elevene på lærerne og hvor mye på hverandre? Likevel er det vel noe $\mathrm{i}$ at kommunikasjonen lærer/elev er preget av enveiskommunikasjon, ettersom det er lærerne som setter premissene for hva som er relevant og hvem som skal snakke.

9) Også dette kan diskuteres: Se på massemønstringer som fotballkamper, Grethe Waitz-løpet og sentrumsløpet i Oslo, folkelivet rundt 5-mila i Holmenkollen. De samler masse folk. Men hva feirer de? Vil alle føle at de har en berettiget og selvskreven plass?

10) Se bl.a. Ekblom 1992 og Kyvsgaard 1990b, som begge gir oversikter over mange undersøkelser av tiltak med sikte på å forebygge lovbrudd.

11) "(K)eeping track of cause and effect is extremely difficult. There may be many other factors at work influencing the level of crime in the experimental area - police patroling, the local economy, the weather even" (Ekblom 1992, s. 78). 
12) Flemming Balvig, 1979.

13) Arbeidet bygger på tre studier av fanger i Sverige som sonet dom for ulike vinningsog narkotikalovbrudd fra 1977 (lydbåndsintervju med fanger og politimenn) 1978 (noen uformelle intervjuer og spørreskjemaundersøkelse med 101 fanger) 1981 (spørreskjema til 150 fanger i ni fengsler og 50 lydbåndintervju) (s. 5).

14) En annen ting er at det fins andre grunner for å straffe: hevn, uskadeliggjøring av lovovertrederen, eller nettopp ikke en primitiv hevn, for "straffen skal (. . .) vare (. . .) uttrykk for det siviliserte samfunns fasthet og normgrunnlag" (Justisministeren 1992). Men det er en annen historie.

15) Kriminalstatistikken 1991. Tabell 28.

16) Se bl.a. Reiss (1992) som diskuterer vanskeligheten med å forutsi farlighet.

17) Åkerstrøm sier for eksempel: "Several scholars react towards therapy. Netter (1978) even refers to "the tyranny of therapy". Cressey (1978) emphasizes the importance of self as one of the few things left during incarceration" (s. 89).

18) Ikke overraskende kanskje. Prevensjon betyr det samme som forebygging. Men selv om ordene er de samme, knytter diskusjonen om "almenprevensjon" og "forebygging" seg til ulike tider, tanker og tiltak. Almenprevensjonen har vært diskutert siden oldtiden, ble aktuell igjen med Beccarias bok fra 1766 og knytter seg først og fremst til straffens avskrekkende virkning. "Forebygging" slik det blir brukt i dagens situasjon, knytter seg til flere forskjellige typer tiltak enn straff.

19) Jon Hellesnes skriver om administrasjonens kolonisering av tenkemåter i: "Systemet, livsverda og mediavaset", 1992. 